\title{
REDESIGN OF JOINT BUSINESS GROUP MANAGEMENT (KUBE) THROUGH DEVELOPMENT OF GROUP SOCIAL COMPANION MODELS
}

\author{
Maya Yusnita \\ Universitas Bangka Belitung \\ E-mail: mayayusnitaubb@gmail.com
}

\begin{abstract}
This study aims to develop a social companion model of the Joint Business Group (KUBE). There were 50 research respondents consisting of KUBE management and assistants in Pangkalpinang. The research method uses a mixed approach. Based on the results of the study, the KUBE social companion model that was developed is the professional assistance model, which starts with the process of selective recruitment of KUBE companions based on competency, followed by training, as well as the obligation to report KUBE developments periodically. In addition, this research produced the following findings: (1) 67\% of training had an impact on companion skills; (3) There is a gap between the supply material and the companion needs by 50\%; (4) It is necessary to improve the quality of the accompanying supplies both in terms of material, method, duration of implementation, instructor and training media; and (5) $58 \%$ of KUBE management felt that the mentor was able to help KUBE activities.
\end{abstract}

Keywords: KUBE, social companion, training

\section{INTRODUCTION}

The problem of poverty is a problem that needs to be dealt with across sectors, together with and synergistically. This is because the problem of poverty is a source of poverty and the development of other social problems (Priadana, 2010). Dimensions of poverty according to Effendi (1995) can be identified according to economic, social and political. Economically, poverty can be interpreted as a lack of resources that can be used to improve the welfare of a group of people. This poverty can be measured directly by determining the supply of natural resources available to the group and comparing it with standard measures.
In this sense poverty of a group of people is linked to income and needs. Estimated needs only refer to basic needs or minimum basic needs for decent living (Sartika, 2016).

Based on Minister of Social Affairs Regulation No. 25 of 2015, the Joint Business Group (KUBE) is a group of poor families that formed, growing and developing on their initiative in carrying out productive economic businesses to increase family income. The results of Iyan Bachtiar's research (2011) stated that the strategies and policies that need to be taken in developing the role of KUBE in improving the economic resilience of rural communities, include: input, formation procedures, 
KUBE environment and organization, KUBE assistance, KUBE implementation and output, as well as outcomes and impacts KUBE.

In running the business, KUBE requires the role of assistants who have the knowledge, skills and commitment to reduce the urban poverty. Assistance is expected to provide convenience to KUBE members in identifying needs, solving problems and developing KUBE. According to Suharto (2009), social assistance can be interpreted as a dynamic interaction between poor groups and social workers to face various challenges such as, designing programs to improve economic life, mobilize local resources, solve social problems, create or open access for meeting needs, establish cooperation with other parties in accordance with the context of community empowerment. KUBE social assistance is one of the strategies in determining the success of the economic empowerment program for the poor (Nurhasanah, 2015). KUBE's assistance needs to be improved and developed so that the effectiveness of KUBE in improving the skills of members is higher and ultimately it can increase the income widely (Wulan, 2019).

Research Suryani et al. (2017) states that the role of the KUBE companion in improving the welfare of its members is quite important, especially in its role as a motivator, facilitator, liaison and defender (advocacy). According to the research by Rahmat Hidayat et al. (2009) found that KUBE assistants in Tangsi Duren had an important role in empowering groups to be able to achieve KUBE achievement at the provincial level. The role of the facilitator who runs actively is continuous with flexible time, namely the information provider, planner, mentor, motivator, facilitator, liaison, mobilizer, advocator, and evaluator. Research by Nurnita Widyakusuma (2013) described that the facilitators as having performed their roles quite well, although not all of the roles they could do. However, in its implementation in the field there are still obstacles, one of them is the amount of honorarium.

On the contrary, research by Muhammadun et al. (2019) showed that partially the KUBE companion's interpersonal communication skills are not significant to the productive economic business performance carried out by KUBE members. Research by Muhammad Ananta Firdaus and Sofyan Cholid (2019) states that there is no relationship between the process of mentoring the District Social Welfare Workers (TKSK) to the achievement of the goals of KUBE.

Based on the data from the Social and Manpower Office of Pangkalpinang City, there were 45 KUBE beneficiaries of productive assistance in 2015. However, the number of KUBE assistants is very minimal at only \pm 5 people. The number of assistants is still considered to be very insufficient to carry out their duties optimally. In addition to the lack of availability of assistants, the appointment system of KUBE social assistants in Pangkalpinang has not gone through a recruitment and selection process that's in accordance with the 
competencies. The provisioning of KUBE social assistants was only done once at the beginning of carrying out their duties. Reports given by KUBE management are also only conducted at the beginning after the grant funds have been received. Furthermore, coordination is only between the social assistance staff and KUBE management. Monitoring and Evaluation conducted by the Department of Social and Labor of Pangkalpinang City has not been felt to be very maximal, so it is necessary to try to increase the frequency of monitoring to ensure the sustainability of KUBE productivity.

\section{LITERATURE REVIEW}

KUBE is a group of poor families that formed, growing and developing on their initiative in carrying out productive economic endeavors to increase family income (Minister of Social Affairs Regulation No. 25 of 2015).

KUBE aims to empower the poor, develop basic social services, increase income, individual capacity, and business ability of group members so that they are able to meet their needs independently and increase social solidarity (Minister of Social Affairs Regulation No. 25 of 2015). Based on Minister of Social Affairs Regulation No. 25 of 2015, the establishment of KUBE is based on the following criteria:

a. Has the potential, willingness and ability to develop joint ventures

b. Having a type of business and living in the village / kelurahan in the same sub-district

c. Has limited access to markets, capital and business
KUBE companion is someone who is assigned to assist the implementation of KUBE in order to improve the welfare of the members (Minister of Social Affairs Regulation No. 25 of 2015). Social assistance according to Edi Suharto (2006) can be interpreted as a dynamic interaction between poor groups and social workers to jointly face a variety of challenges such as: (1) Designing programs to improve socio-economic life; (2) Mobilizing local resources; (3) Solving social problems; (4) Creating or opening access for meeting needs; and (5) Collaborating with various parties relevant to the context of community empowerment (Suitela, 2017).

The Ministry of Social Affairs has calcified the social assistance model as follows:

1. Professional Assistance

Professional assistants are social assistants who have the discipline of social work, with a Diploma or Bachelor degree in Social Work, the appointment is based on selection carried out by the institution and has concern for social problems faced by the community and is ready to be in the location to be handled.

2. Conventional Assistance

Conventional assistants are facilitators who come from local communities and are not based on formal education in social work, but have concern for social problems that exist in the community without orders from local village. This assistance model is still very traditional because it only relies on the call of heart (volunteers). 


\section{METHODS}

This type of research was a research with quantitative and qualitative approaches. The stages in this study are as follows:

1. Literature Study

2. Field Survey

3. Distribution of questions / questionnaires.

4. Focus Group Discussion (FGD)

5. The developed model is then tested on KUBE social assistants through 2 (two) stages, namely:

a. Model Building (Constructing or Developing Models), using survey research and literature study.

b. Model Testing, by testing whether the model is in accordance with the capabilities and expectations of the KUBE social companion.

include:

The types of data in this study

1. Qualitative data, values of changes that cannot be expressed in numbers.

2. Quantitative data, namely analysis by processing data from research results that have been stated in units of numbers to be analyzed by statistical calculations of the object variables studied.

Data collection methods in this study use 2 (two) types of data, namely as follows:

a. Primary Data is data of research results obtained from respondents both through Focus Group Discussions (FGD) or by interview methods.

b. Secondary data is data obtained from literature books, implementation instructions and technical instructions about KUBE social assistance.

The data analysis method uses descriptive qualitative and quantitative analysis to explain or describe the data in this study.

\section{RESULTS AND DISCUSSION}

Focus Group Discussion (FGD) was held in the Meeting Room of the Social Service Office of the Bangka Belitung Islands Province. The activity was officially opened by the Head of the Bangka Belitung Islands Province Social Service. The number of participants who attended was 50 people consisting of KUBE management and assistants in Pangkalpinang.

Respondents in this study were 50 people consisting of KUBE management and assistants in Pangkalpinang. However, after the checking, the questionnaires were filled out completely and deserved to be analyzed as many as 38 questionnaires consisting of 32 KUBE administrators and 6 KUBE assistants.

Table 1. Identity of KUBE Management according to Age

\begin{tabular}{cc}
\hline Age (Years) & $\begin{array}{c}\text { Number of } \\
\text { Respondents } \\
\text { (People) }\end{array}$ \\
\hline$<30$ & 1 \\
\hline $30-40$ & 14 \\
\hline $41-50$ & 15 \\
\hline$>50$ & 2 \\
\hline Total & 32 \\
\hline
\end{tabular}

Table 1 shows by grouping based on age, it can be explained that 
the average age of KUBE management is in the range of $30-40$ years $(43.75 \%)$ and $41-50$ years $(46.8 \%)$, while the smallest range is age $<30$ The year is only 1 person.

Table 2. Identity of KUBE Companions by Age

\begin{tabular}{cc}
\hline Age (Years) & $\begin{array}{c}\text { Number of } \\
\text { Respondents } \\
\text { (People) }\end{array}$ \\
\hline$<30$ & 2 \\
\hline $30-40$ & 3 \\
\hline $40-50$ & 1 \\
\hline Total & 6 \\
\hline
\end{tabular}

Table 2 shows that by grouping by age, it can be explained that KUBE companions are on average $30-40$ years old $(50 \%)$.

Table 3. Identity of KUBE Management according to Gender Number of

Gender Respondents (People)

\begin{tabular}{cc}
\hline Male & 11 \\
\hline Female & 21 \\
\hline Total & 32 \\
\hline
\end{tabular}

The identity of respondents by gender can be seen in Table 3 above. Based on the table, it can be seen that, from 32 respondents, the average KUBE management is female, with 21 people $(65.62 \%)$.

Table 4. Identity of KUBE Companions by Gender

\begin{tabular}{cc}
\hline Gender & $\begin{array}{c}\text { Number of } \\
\text { Respondents } \\
\text { (People) }\end{array}$ \\
\hline Male & 4 \\
\hline Female & 2 \\
\hline Total & 6 \\
\hline
\end{tabular}

Based on the table, it can be seen that the spread of gender in KUBE assistants is dominated by men by $66.67 \%$. Descriptive analysis is used to determine the distribution of respondents' answers from the questionnaire. There were 21 questions distributed to the facilitators and 9 questions to the KUBE management. The following is a summary of the results of the respondents' answers.

Table 5. Description of KUBE Companion's Answers

\begin{tabular}{lc}
\hline \multicolumn{1}{c}{ Category } & Dominant Answer (\%) \\
\hline Following the training & Yes, 100\% \\
\hline $\begin{array}{l}\text { Training can help in the Implementation } \\
\text { of Group Assistance }\end{array}$ & Strongly Agree, 100\% \\
\hline $\begin{array}{l}\text { The effect of training on KUBE } \\
\text { Companion Skills }\end{array}$ & Strongly Agree, 67\% \\
\hline $\begin{array}{l}\text { The training adds knowledge } \\
\text { The training adds competence in jobs }\end{array}$ & Strongly Agree, 83\% \\
\hline $\begin{array}{l}\text { The training helps solve the problems of } \\
\text { KUBE }\end{array}$ & Strongly Agree, 83\% \\
\hline $\begin{array}{l}\text { The gap between the training content and } \\
\text { companion needs }\end{array}$ & Agree, 50\% \\
\hline The opinions regarding the appointment & Agree, 50\% \\
\hline
\end{tabular}




\begin{tabular}{lc}
\hline \multicolumn{1}{c}{ Category } & Dominant Answer (\%) \\
\hline $\begin{array}{l}\text { of a companion } \\
\text { Selective recruitment }\end{array}$ & Strongly Agree, 50\% \\
\hline $\begin{array}{l}\text { The efficiency of training that } \\
\text { implemented by social affairs }\end{array}$ & Agree, 67\% \\
\hline The accuracy of the training's material & Agree, 67\% \\
\hline The suitability of the training's method & Agree, 83\% \\
\hline The Effectiveness of the training's period & Agree, 67\% \\
\hline $\begin{array}{l}\text { The suitability of the training instructor } \\
\text { with his background/job }\end{array}$ & Strongly Agree, 67\% \\
\hline The completeness of the training's media & Agree, 83\% \\
\hline $\begin{array}{l}\text { The suitabilty of the training process with } \\
\text { the companion level }\end{array}$ & Agree, 100\% \\
\hline Advanced training required & Strongly Agree, 50\% \\
\hline $\begin{array}{l}\text { Future Change Requirements are Required } \\
\text { Evaluation of training }\end{array}$ & Strongly Agree, 50\% \\
\hline $\begin{array}{l}\text { Companion's attitudes towards the training } \\
\text { Partnership between the government and } \\
\text { the community is needed in assistance }\end{array}$ & Strongly Agree, 100\% \\
\hline
\end{tabular}

Table 6. Description of KUBE Management's Answers

\begin{tabular}{|c|c|}
\hline Category & Dominant Answer (\%) \\
\hline The benefits of assistance for KUBE & Strongly Agree, $100 \%$ \\
\hline $\begin{array}{l}\text { Assistance in accordance with the } \\
\text { expectations }\end{array}$ & Strongly Agree, $90 \%$ \\
\hline Group assistance management & Quite Agree, $47 \%$ \\
\hline $\begin{array}{l}\text { The opinions about the existence of a } \\
\text { companion officer }\end{array}$ & Strongly Agree, $56 \%$ \\
\hline The companion helps solve the problems & Strongly Agree, $72 \%$ \\
\hline $\begin{array}{l}\text { The companion helps the operational of } \\
\text { KUBE }\end{array}$ & Strongly Agree, $56 \%$ \\
\hline $\begin{array}{l}\text { The companion helps the basic needs of } \\
\text { the member of KUBE }\end{array}$ & Agree, $50 \%$ \\
\hline The companion increases KUBE's income & Agree, $53 \%$ \\
\hline $\begin{array}{l}\text { The knowledge provided by the } \\
\text { companion is in accordance with the } \\
\text { capabilities }\end{array}$ & ee, $65 \%$ \\
\hline
\end{tabular}

Based on the data that has been collected both through literature review, observation, interviews, questionnaires and Focus Group Discussion (FGD), the KUBE social companion model developed is in accordance with the Ministry of Social's classification which is a professional assistance model where social assistants have the discipline of social work science, with a Diploma or Bachelor degree in Social Work, the appointment is based on selection carried out by the institution and has concern for social problems faced by the community 
and ready to be in the location to be handled. The process of selective recruitment of KUBE's companion based on competency, followed by training, as well as the obligation to report KUBE developments periodically. The model developed is through two stages as follows:

a. Model Building (Constructing or

Developing Models) using this

type of survey research and literature study.

b. Model Testing, by testing whether the model is in accordance with the capabilities and expectations of the KUBE social companion.

The steps for developing KUBE's social companion model in Pangkalpinang are as shown in Figure 1 below:

Figure 1. Steps for Development of KUBE's Social Companion Model

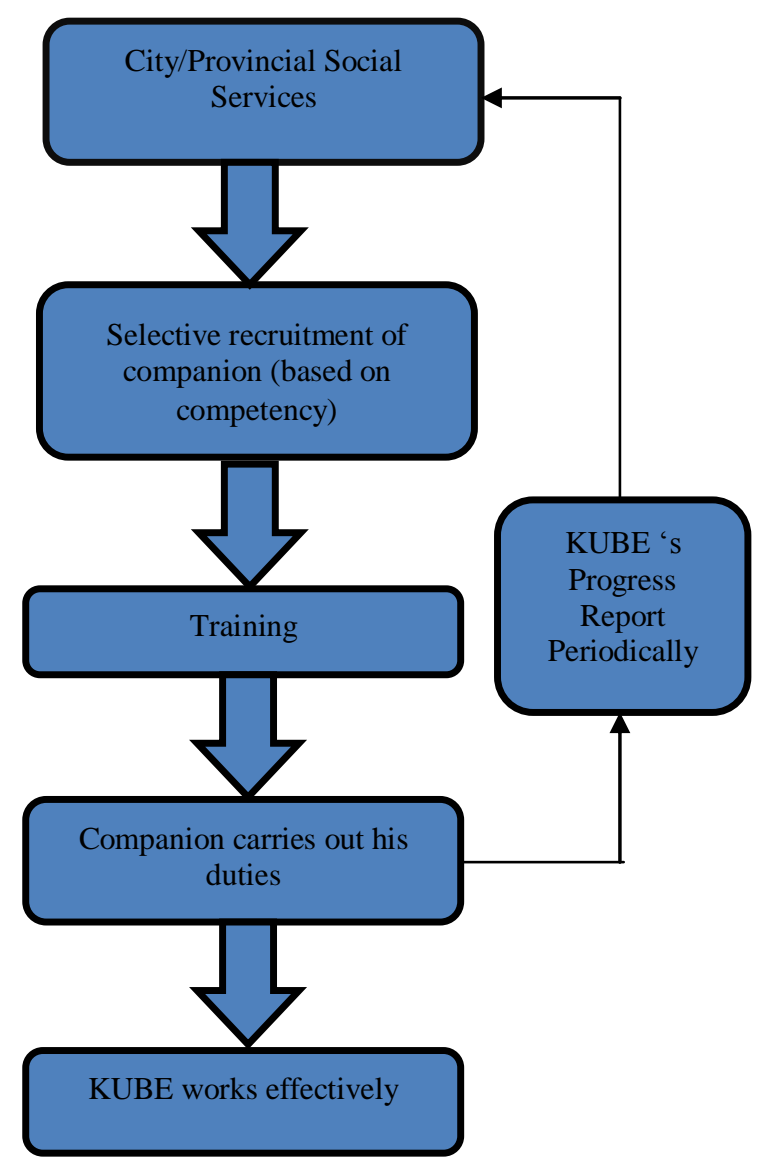

\section{CONCLUSION}

Based on the research findings, the conclusion is KUBE social assistant model developed according to the Ministry of Social RI classification is a professional assistance model where social assistants have the discipline of social work, with a Diploma or
Bachelor of Social Work education level, the appointment is based on selection carried out by the institution and has concern for social problems faced by the community and ready to be in the location to be handled. 


\section{REFERENCES}

Bachtiar, Iyan dan Jamaludin. 2011. Studi Pola Pelaksanaan Kelompok Usaha Bersama (KUBE) dan Tingkat Keberhasilannya dalam Meningkatkan Perekonomian Masyarakat Miskin Desa, Studi Kasus: Kelompok Usaha Bersama (KUBE) di Kabupaten Tasikmalaya. Prosiding SnaPP2011 Sains, Teknologi, dan Kesehatan ISSN: 2089-3582.

Firdaus, Muhammad Ananta\&Sofyan Cholid. 2019. Pengaruh Proses Pendampingan Sosial Tenaga Kesejahteraan Sosial Kecamatan (TKSK) terhadap Pencapaian Tujuan Kelompok Usaha Bersama Fakir Miskin (KUBE-FM) di Kota Jambi. Biyan: Jurnal Ilmiah Kebijakan dan Pelayanan Pekerjaan Sosial Vol. 01 No. 1, Juli 2019.

Hidayat, Rahmat dkk. 2009. Peranan Pendamping Kelompok Usaha Bersama (KUBE) dalam Pemberdayaan Fakir Miskin (Studi Komparatif di KUBE "Welas Asih" Desa Tangsi "Duren dan KUBE "Bina Tani” Kelurahan Tangsi Baru Kecamatan Kabawetan Kabupaten Kepahiang. Tesis.

Muhammadun dkk. 2019. Pengaruh Kemampuan Komunikasi Interpersonal Pendamping Sosial dengan Anggota Kelompok Usaha Bersama terhadap Kinerja Usaha Ekonomi Produktif di Kota Banjarmasin. AL-ULUM ILMU SOSIAL DAN HUMANIORA Volume 5 Nomor 1, April 2019. ISSN: 2476-9576.

Nurhasanah, Siti dkk. 2015. Pelatihan Pendamping Sosial dalam meningkatkan Kemampuan Fasilitasi Program Kelompok Usaha Bersama. Pedagogia: Jurnal Ilmu Pendidikan.

Peraturan Menteri Sosial Republik Indonesia Nomor 25 Tahun 2015 tentang Kelompok Usha Bersama.

Priadana, Moh. Sidik \& Effendi M. Guntur. 2010. Analisis Faktor Penentu Keberhasilan serta Dampak dari Kelompok Usaha Bersama di Jawa Barat. Trikonomika Vol. 9 No. 2, ISSN: 1411-514X.

Sartika, Cica dkk. 2016. Studi Faktor-faktor Penyebab Kemiskinan Masyarakat Desa Lohia Kecamatan Lohia Kabupaten Muna. Jurnal Ekonomi (JE) Vol. 1 (1), EISSN: 2503-1937.

Suitela, Josias Jefry. 2017. Pendampingan Sosial dalam Pengembangan Kapasitas Kelompok Usaha Bersama di Bandung. PEKSOS: Jurnal Ilmiah Pekerjaan Sosial Vol. 16 No. 1, Juni 2017.

Suryani\&Akhmad Purnama. 2017. Peran Pendamping KUBE-FM 
dalam meningkatkan Kesejahteraan Anggotanya. Media Informasi Penelitian Kesejahteraan Sosial Vol. 41 No. 1 April 2017.

Widyakusuma, Nurnita. 2013. Peran Pendamping dalam Program Pendampingan dan Perawatan Sosial Lanjut Usia di Lingkungan Keluarga (Home Care): Studi tentang Pendamping di Yayasan Pitrah Sejahtera, Kelurahan Clincing,
Kecamatan Clincing Jakarta Utara. Informasi Vol. 18 No. 02 .

Wulan, Yuni Catur dkk. 2019. Implementasi Kebijakan Penanggulangan Kemiskinan melalui Program Pemberdayaan Ekonomi Kelompok Usaha Bersama (KUBE). Jurnal Respon Publik Volume 13 Nomor 4 Tahun 2019, ISSN 2302-8432. 